Novia Citra Praingsih, Prabang Setyono, Sunarto. (2018). Konservasi Mangrove Berbasis TRM (Tanam Rawat Monitoring) untuk Menjaga Sumberdaya Laut di Cengkrong, Trenggalek. Jurnal Bioeksperimen. Vol. 4 (2) Pp. $22-34$. Doi: $10.23917 /$ bioeksperimen.v4i1.2795

\title{
Konservasi Mangrove Berbasis TRM (Tanam Rawat Monitoring) untuk Menjaga Sumberdaya Laut di Cengkrong, Trenggalek
}

\author{
Novia Citra Paringsih ${ }^{1}$, Prabang Setyono ${ }^{2}$, Sunarto ${ }^{3}$ \\ ${ }^{1}$ Pascasarjana Ilmu Lingkungan Universitas Sebelas Maret Surakarta Jl. Sutami 36 A Surakarta, 085736449670 \\ ${ }^{2}$ Fakultas MIPA Universitas Sebelas Maret Surakarta JL. Sutami 36 A Surakarta \\ ${ }^{3}$ Fakultas MIPA Universitas Sebelas Maret Surakarta JL. Sutami 36 A Surakarta \\ *e-mail :noviacitra@ymail.com
}

\begin{abstract}
Abstrak
Hutan Mangrove terletak di Kabupaten Trenggalek, Jawa Timur telah mengalami penurunan spesies diakibatkan perilaku konsumtif masyarakat dalam memanfaatkan mangrove. Keberadaan mangrove sangat penting untuk menjaga kesetabilan sumberdaya laut khususnya perikanan. Penelitian ini bertujuan untuk mengetahui Indeks Nilai Penting (INP) pada tiga zonasi, melakukan pendekatan kepada masyarakat sekitar terkait partisipasi dalam konservasi mangrove, dan membuat strategi konservasi hutan mangrove berbasis Tanam Rawat Monitoring. Metode penelitian deskriptifkuantitatif, pengambilan data mangrove random sampling dan pengambilan data wawancara kepada masyarakat sekitar purposive sampling. Analisis vegetasi menggunakan Indeks Nilai Penting, analisis partisipasi masyarakat menggunakan Pressure State Response. Hasil penelitian zonasi A didominasi Sonneratia alba (99,84\%) kategori pohon, Sonneratia alba (89,03\%) kategori anakan pohon, Rhizophora mucronata (80,74\%) kategori semai, zonasi B didominasi Sonneratia alba (120,57\%) kategori pohon, Sonnratia alba (57,55\%) kategori anakan pohon, Sonneratia alba, Ceriops tagal, Rhizophora apiculata (32,47\%) kategori semai, zonasi C didominasi Lumnitzera racemosa (132,40\%) kategori pohon, Xylocarpus granatum (113,03\%) kategori anakan pohon, Lumnitzera racemosa (60,28\%) kategori semai. Pendekatan partisipatif dan kemitraan kepada masyarakat sekitar melalui Pokmaswas Kejung Samudera berjalan lancar. Kesimpulannya konservasi berbasis Tanam Rawat Monitoringdi kawasan mangrove Cengkrong lebih efektif untuk diterapkan, konservasi mangrove tersebut diharapkan dapat menjadi role model masyarakat untuk menjaga hutan mangrove dan sumberdaya laut.
\end{abstract}

Kata kunci: Konservasi, Mangrove, TRM (Tanam Rawat Monitoring), Sumberdaya, Laut.

\section{Pendahuluan}

Kawasan mangrove Cengkrong terletak di Desa Karanggandu, Kecamatan Watulimo, Kabupaten Trenggalek, Provinsi Jawa Timur. Luas kawasan mangrove Cengkrong \pm 87 ha. Kondisi rusak berat \pm 5 ha dan rusak ringan \pm 32 ha (DKP, 2016). Tahun 2002 sampai 2016 mulai dilakukan penanaman kembali spesies mangrove yang sudah hilang. Kegiatan penanaman mangrove tersebut diprakarsai oleh Dinas Kelautan Perikanan (DKP) yang bekerjasama dengan Perhutani dan masyarakat sekitar yang peduli dengan keberadaan kawasan mangrove. Penanaman kembali spesies mangrove yang telah hilang terkait dengan UU
No.27 tentang kelestarian lingkungan hidup dan khusus untuk Kabupaten Trenggalek terdapat Peraturan Daerah No. 10 Tahun 2004 tentang pengelolaan sumberdaya perikanan. Masyarakat Kabupaten Trenggalek umumnya dan khususnya yang berada di sekitar kawasan mangrove Cengkrong, dihimbau untuk menjaga kelestarian mangrove. Hal tersebut disebabkan Kecamatan Watulimo khususnya Desa Karanggandu dan Desa Prigi memilikli aset penghasilan terbesar pada sumber daya laut bidang perikanan (Purwanti et al., 2015). Mangrove mempunyai peran penting dalam menjaga kesetabilan kondisi daratan dan lautan (Zamroni et al., 2008; Kartijono et al., 2010; Kustanti, 2011; Susanto et al., 2013). Kerusakan 
mangrove di Cengkrong disebabkan adanya alih fungsi lahan oleh masyarakat sekitar yang belum memahami pentingnya mangrove bagi ekosistem laut. Yanuartati (2015) menyatakan bahwa kerusakan mangrove juga diakibatkan karena pertambahan populasi manusia dengan kebutuhan ekonomi yang meningkat. Kerusakan mangrove jika dibiarkan tanpa ada suatu penanganan yang intensif dikhawatirkan semakin meluas dan berdampak pada ekosistem laut yang tidak setabil, sehingga hasil perikanan tangkap menurun (Orizal et al., 2008). Pranata et al. (2015) menyatakan bahwa kesejahteraan masyarakat pesisir tergantung pada sumberdaya perikanan, sehingga kondisi lingkungan laut menentukan kesejahteraan perekonomian masyarakat setempat.

Upaya rehabilitasi dalam rangka konservasi yang sudah dilakukan oleh Dinas Kelautan Perikanan dengan penanaman kembali spesies mangrove yang telah hilang untuk mengembalikan ke fungsi semula belum mencapai tahap maksimal, karena masih ada mangrove yang mengalami kerusakan.

Riset tentang strategi konservasi mangrove perlu dilakukan dengan konsep konservasi mangrove berbasis TRM yang bertujuan untuk (1) mengetahui INP (Indeks Nilai Penting) mangrove di zonasi A 50 meter dari pantai, zonasi B 50 meter dari sungai, dan zonasi C 50 meter dari darat, (2) melakukan pendekatan kepada masyarakat sekitar terkait partisipasi dalam konservasi mangrove, (3) membuat strategi konservasi hutan mangrove berbasis TRM.

\section{Metode}

\section{Tempat dan Waktu Penelitian}

Lokasi penelitian berada di kawasan hutan mangrove Desa Karanggandu, Kecamatan Watulimo, Kabupaten Trenggalek, Provinsi Jawa Timur. Lokasi ini dipilih karena Desa Karanggandu berbatasan dengan Desa Prigi, merupkan salah satu daerah penghasil
Perikanan tangkap terbesar di Kecamatan Watulimo, namun demikian dengan kondisi mangrove yang mengalami kerusakan, hal tersebut mengakibatkan ekosistem laut tidak setabil dan hasil perikanan tangkap mengalami penurunan. Penanganan permasalahan kerusakan mangrove telah dilakukan oleh DKP Kabupaten Trenggalek berupa penanaman kembali spesies mangrove yang rusak, namun demikian penanganan tersebut belum optimal, bahkan masih ada mangrove yang mengalami kerusakan.

Waktu yang digunakan untuk penelitian ini tiga bulan (September sampai November 2016).

\section{Metode Penelitian}

Penelitian ini secara deskriptif kuantitatif. Data yang digunakan berupa data primer dan data sekunder. Data primer diperoleh melalui wawancara kepada masyarakat Desa Karanggandu secara purposive sampling (Noor, 2011). Pengambilan sampel masyarakat sebanyak 33 orang dari anggota Pokmaswas Kejung Samudera. Menghitung INP mangrove pada tiga zonasi yang berbeda dengan membuat plot $10 \times 10 \mathrm{~m}$ untuk kategori pohon, $5 \times 5 \mathrm{~m}$ untuk kategori anakan pohon, dan 1x1 m untuk kategori semai, dengan ulangan sebanyak 3 kali pada masing-masing zonasi. Zonasi A berada pada jarak $50 \mathrm{~m}$ dari pantai, zonasi B berada pada jarak $50 \mathrm{~m}$ dari sungai, zonasi $\mathrm{C}$ berada pada jarak 50 m dari darat (Krebs, 1972). Data sekunder diperoleh melalui penelusuran dokumen dan informasi ke Dinas Kelutan Perikanan Trenggalek, Perum Perhutani, Kantor Kecamatan Watulimo, dan Kantor Desa Karanggandu. Jenis data sekunder yang dikumpulkan terkait dengan kondisi umum lokasi penelitian di hutan mangrove Cengkong Desa Karanggandu.

\section{Metode Analisis Data}

Analisis Vegetasi untuk mengetahui spesies mangrove yang mendominasi pada suatu wilayah, dihitung dengan rumus: 
Kerapatan $(\mathrm{K})=$ jumlah individu suatu spesies

Luas seluruh plot

Kerapatan Relatif $(\mathrm{KR})=$ kerapatan suatu spesies X 100\%

kerapatan seluruh spesies

Frekuensi $(\mathrm{F})=$ jumlah plot yang ditempati suatu spesies

Jumlah plot sluruh pengamatan

Frekuensi Relatif $(\mathrm{FR})=$ frekuensi suatu spesies X 100\%

frekuensi seluruh spesies

Dominansi $(\mathrm{D})=$ jumlah basal area suatu spesies

luas seluruh plot

Dominansi Relatif $(\mathrm{DR})=$ dominansi suatu spesies X 100\%

dominansi seluruh spesies

Indeks nilai penting pohon dan pancang $=\mathrm{KR}$ $+\mathrm{FR}+\mathrm{DR}$

Indeks nilai penting semai, semak, herba $=\mathrm{KR}$ + FR (Krebs, 1972).

Analisis partisipatif kepada masyarakat anggota Pokmaswas Kejung Samudera menggunkan Pressure State Response, yaitu dengan melakukan penilaian terhadap partisipasi secara langsung dan partisipasi secara tidak langsung (Susilowati, 2012).

\section{Hasil dan Pembahasan}

\section{Gambaran Umum Mangrove di Cengkrong}

Kawasan Mangrove Cengkrong berada di lokasi strategis jalur lintas selatan yang menghubungkan Jawa Timur dan Jawa Tengah. Batas administratif sebelah utara berbatasan dengan Desa Prigi, sebelah selatan berbatasan dengan teluk damas, sebelah barat berbatasan dengan Desa Margomulyo, dan sebelah timur berbatasan dengan Desa Tasikmdu (BPS, 2016). Mangrove tumbuh di kawasan akuatik yang memiliki karakteristik tumbuh di daerah pantai yang beriklim tropis (Chandra, 2011). Kawasan Mangrove Cengkrong merupakan penyeimbang ekosistem laut yang ada di Cengkrong dan Prigi. Peta Kawasan Mangrove Cengkrong disajikan pada Gambar 1.

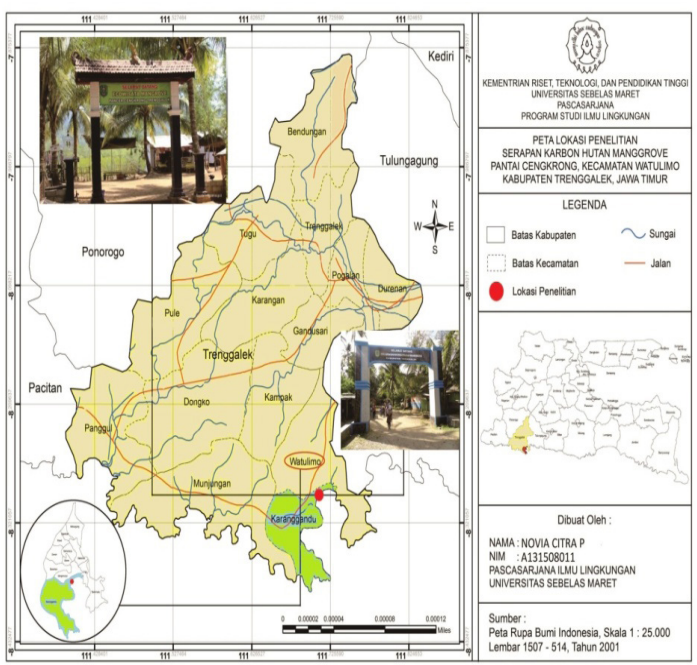

Gambar 1. Lokasi Mangrove Cengkrong

\section{Indeks Nilai Penting Mangrove di Cengkrong.}

Kawasan Mangrove Cengkrong terdapat 4 spesies pionir terdiri dari Bruguiera gymnorrhiza, Sonneratia alba, Rhizophora mucronata, Ceriops decandra, dan Xylocarpus sp. Spesies pioner merupakan spesises mangrove yang mampu tumbuh pada kondisi lingkungan ekstrim (Noor et al., 2012; Sarno, 2016). Kisaran salinitas yang sesuai untuk pertumbuhan mangrove adalah 2-22 ppt (Sulastini, 2011).Van et al. (2015) menyatakan bahwa tumbuhan mangrove memiliki jenis yang heterogen. Spesies mangrove yang terdapat di Cengrong rendah. Hal tersebut bisa dilihat pada data hasil analisis vegetasi.

Data hasil analisis vegetasi digunakan untuk mengetahui seberapa besar spesies yang 
mendominasi pada suatu zonasi, ketika proses konservasi akan dilaksanakan (Krebs, 1972). Spesies tumbuhan di hutan mangrove memiliki dinamika yang disebabkan oleh adanya faktor alamiah ataupun aktivitas manusia (Kaunang et al., 2009). Dinamika tinggi atau rendahnya spesies yang mendominasi pada suatu zonasi dipengaruhi oleh aktivitas masyarakat yang ada di sekitar hutan mangrove dan juga faktor lingkungan (Elhaq et al., 2011). Hasil analisis faktor lingkungan disajikan pada Gambar 2.

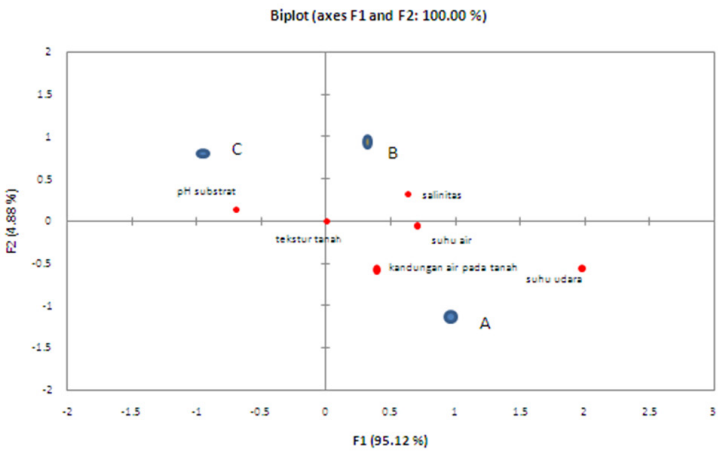

Gambar 2. Hasil Analisis Faktor Lingkungan

Keterangan:

ZonasiA $=50 \mathrm{~m}$ dari pantai

ZonsaiB $=50 \mathrm{~m}$ dari sungai

Zonasi $\mathrm{C}=50 \mathrm{~m}$ dari darat

Faktor lingkungan yang berpengaruh terhadap kelangsungan hidup tumbuhan mangrove adalah suplai air tawar, salinitas, pasokan nutrient, dan stabilitas substrat (Dahuri et al., 2001). Faktor lingkungan yang tinggi pada zonasi A terdiri dari suhu air $\left(31^{\circ} \mathrm{C}\right)$, suhu udara $\left(32^{\circ} \mathrm{C}\right)$, salinitas $(6 \mathrm{ppt})$, dan kandungan air pada tanah (57,7\%). Disebabkan letak zonasi A berada di dekat pantai dengan intensitas cahaya matahari yang optimal, sehingga suhu udara tinggi otomatis suhu air juga tinggi. Kandungan air dalam tanah dan salinitas di zonasi A tinggi. Disebabkan posisi kawasan zonasi A berada paling dekat laut dan sering mengalami genangan air payau ketika pagi hari dan saat terjadi pasang. Mahmudi et al. (2007) menyatakan bahwa suhu perairan mangrove sebesar $\left(30-32^{\circ} \mathrm{C}\right)$ berarti kondisi perairan di sekitar mangrove masih sesuai dengan kehidupan mangrove.

Faktor lingkungan yang tinggi pada zonasi $\mathrm{B}$ adalah salinitas (6 ppt). Hal tersebut dikarenakan letak zonasi B berada di sekitar sungai, namun masih mendapat aliran air laut sehingga salinitasnya sama dengan zonasi A dan lebih besar dari zonasi C. Saputra (2003) menyatakan bahwa salinitas sebesar 2-22 ppt sesuai untuk pertumbuhan mangrove.

Faktor lingkungan yang tinggi pada zonasi $\mathrm{C}$ adalah $\mathrm{pH}$ substrat $(6,9)$. Hal tersebut disebabkan letak zonasi $\mathrm{C}$ berbatasan langsung dengan darat, namun masih mendapat genangan air payau, sehingga kondisi $\mathrm{pH}$ substrat mendekati 7 atau hampir mendekati basa. Tekstur tanah pada ketiga zonasi tergolong jenis tanah liat.

Secara keseluruhan kondisi faktor lingkungan di kawasan mangrove Cengkrong terdiri dari suhu air, suhu udara, kandungan air pada tanah, salinitas, tekstur tanah dan $\mathrm{pH}$ substrat, secara umum masih sesuai dengan batas toleransi untuk kehidupan tumbuhan mangrove. Karakteristik hutan mangrove adalah tumbuh pada daerah intertidal dengan jenis tahan berlumpur, berlempung, atau berpasir, daerah tergenang air laut secara berkala, maupun pada saat pasang purnama, frekuensi genangan menentukan komposisi vegetasi hutan mangrove (Bengen, 2000).

Analisis vegetasi zonasi A Kategori pohon yang berada di lokasi $50 \mathrm{~m}$ dari pantai disajikan pada Tabel 1.

Tabel 1. Indeks Nilai Penting Kategori Pohon

\begin{tabular}{ccrrrl}
\hline No. & S & KR(\%) & FR(\%) & DR(\%) & INP \\
\hline 1 & Rm & 0,00 & 28,57 & 19,10 & 47,68 \\
2 & Sa & 37,50 & 28,57 & 33,77 & $\mathbf{9 9 , 8 4}$ \\
3 & Cd & 24,99 & 14,29 & 18,25 & 57,54 \\
4 & Ct & 24,99 & 14,29 & 18,13 & 57,42 \\
5 & Aa & 12,50 & 14,29 & 10,74 & 37,53 \\
\hline
\end{tabular}

Keterangan:

$\mathrm{S} \quad=$ Spesies

$\mathrm{KR}=$ Kerapatan Relatif 


$\begin{array}{ll}\mathrm{FR} & =\text { Frekuensi Relatif } \\ \mathrm{DR} & =\text { Dominansi Relatif } \\ \mathrm{INP} & =\text { Indeks Nilai Penting } \\ \mathrm{Rm} & =\text { Rhizophora mucronata } \\ \mathrm{Sa} & =\text { Sonneratia alba } \\ \mathrm{Cd} & =\text { Ceriops decandra } \\ \mathrm{Ct} & =\text { Ceriops tagal } \\ \mathrm{Aa} & =\text { Avicennia alba }\end{array}$

Kategori anakan pohon pada zonasi Adisajikan pada Tabel 2.

Tabel 2. Indeks Nilai Penting Kategori Anakan Pohon.

\begin{tabular}{cccccc}
\hline No. & S & KR(\%) & FR(\%) & DR(\%) & INP \\
\hline 1 & Bg & 11,11 & 10 & 10,73 & 31,84 \\
2 & Rm & 16,67 & 20 & 21,84 & 58,51 \\
3 & Sa & 27,78 & 30 & 31,25 & 89,03 \\
4 & Cd & 15,74 & 10 & 17,41 & 43,15 \\
5 & Ct & 11,11 & 10 & 9,86 & 30,98 \\
6 & Aa & 7,41 & 10 & 3,28 & 20,68 \\
7 & Ra & 10,19 & 10 & 5,63 & 25,82 \\
\hline
\end{tabular}

Keterangan:

$\begin{array}{ll}\mathrm{S} & =\text { Spesies } \\ \mathrm{KR} & =\text { Kerapatan Relatif } \\ \mathrm{FR} & =\text { Frekuensi Relatif } \\ \mathrm{DR} & =\text { Dominansi Relatif } \\ \mathrm{INP} & =\text { Indeks Nilai Penting } \\ \mathrm{Bg} & =\text { Bruguiera gymnorrhiza } \\ \mathrm{Rm} & =\text { Rhizophora mucronata } \\ \mathrm{Sa} & =\text { Sonneratia alba } \\ \mathrm{Cd} & =\text { Ceriops decndra } \\ \mathrm{Ct} & =\text { Ceriops tagal } \\ \mathrm{Aa} & =\text { Avicennia alba } \\ \mathrm{Ra} & =\text { Rhizophora apiculata }\end{array}$

Sonneratia alba mendominasi zonasi A pada kategori pohon dan anakan pohon, disebabkan Sonneratia alba merupakan spesies mangrove pionir yang mampu tumbuh pada kondisi lingkungan ekstrim (Noor et al., 2012). Masyarakat di sekitar Cengkrong memanfaatkan buah Sonneratia alba untuk dijadikan sebagai bahan dasar pembuatan sirup, dodol, dan manisan. Berbeda dengan Avicennia alba jumlahnya sangat rendah di zonasi A, disebabkan aktivitas masyarakat sekitar adalah memanfaatkan kayu Avicennia alba sebagai bahan bakar, sehingga banyak yang ditebang (Dahdouh-Guebas et al., 2000). Ditinjau dari kondisi salinitas zonasi A sebesar 6 ppt, menandakan bahwa perairan di zonasi A tergolong payau. Noor et al. (2012) menyatakan bahwa Avicennia alba akan tumbuh optimal pada kondisi perairan lebih dari 7 ppt. Kategori semai pada zonasi A disajikan pada Tabel 3.

Tabel 3. Indeks Nilai Penting Kategori Semai

\begin{tabular}{ccccc}
\hline No & S & KR(\%) & FR(\%) & INP \\
\hline 1 & $\mathrm{Rm}$ & 43,24 & 37,5 & $\mathbf{8 0 , 7 4}$ \\
2 & $\mathrm{Ra}$ & 16,22 & 12,5 & 28,72 \\
3 & $\mathrm{Aa}$ & 21,62 & 25 & 46,62 \\
4 & $\mathrm{Ct}$ & 10,81 & 12,5 & 23,31 \\
5 & $\mathrm{Bg}$ & 8,11 & 12,5 & 20,61 \\
\hline
\end{tabular}

Keterangan:

$\mathrm{S}=$ Spesies

$\mathrm{KR}=$ Kerapatan Relatif

FR = Frekuensi Relatif

INP = Indeks Nilai Penting

$\mathrm{Rm} \quad=$ Rhizophora mucronata

$\mathrm{Ra} \quad=$ Rhizophora apiculata

$\mathrm{Aa} \quad=$ Avicennia alba

$\mathrm{Ct}=$ Ceriops tagal

$\mathrm{Bg} \quad=$ Bruguiera gymnorrhiza

Indeks Nilai Penting (INP) Rhizophora mucronata mendominasi pada zonasi A kategori semai, hal tersebut disebabkan sistem perkembangbiakan terjadi sepanjang tahun (Noor et al., 2012). Masyarakat setempat memanfaatkan Rhizophora mucronata sebagai pematang tambak, sehingga pohonnya jarang untuk ditebang. Hal tersebut berbeda dengan spesies Bruguiera gymnorrhiza yang memiliki jumlah INP sangat rendah pada zonasi A, disebabkan propagul sering terbawa aliran air ketika pasang, sehingga propagul tidak menetap pada substrat yang ada di sekitar pohon, hal tersebut akan berpengaruh pada pertumbuhan calon individu baru (De Silva et al., 2010; Noor et al., 2012). 
Analisis vegetasi zonasi B Kategori pohon yang berada di lokasi $50 \mathrm{~m}$ dari sungai disajikan pada Tabel 4.

Tabel 4. Indeks Nilai Penting Kategori pohon

\begin{tabular}{cccccc}
\hline No & S & KR(\%) & FR(\%) & DR(\%) & INP \\
\hline 1 & Aa & 26,32 & 16,67 & 1,15 & 44,13 \\
2 & Rm & 10,53 & 8,33 & 0,50 & 19,36 \\
3 & Sc & 15,79 & 16,67 & 0,44 & 32,90 \\
4 & Cd & 10,53 & 16,67 & 0,44 & 27,63 \\
5 & Ct & 13,16 & 8,33 & 0,60 & 22,09 \\
6 & Bg & 15,79 & 16,67 & 0,85 & 33,31 \\
7 & Sa & 7,89 & 16,67 & 96,01 & 120,57 \\
\hline
\end{tabular}

Keterangan:

$\begin{array}{ll}\mathrm{S} & =\text { Spesies } \\ \mathrm{KR} & =\text { Kerapatan Relatif } \\ \mathrm{FR} & =\text { Frekuensi Relatif } \\ \mathrm{DR} & =\text { Dominansi Relatif } \\ \mathrm{INP} & =\text { Indeks Nilai Penting } \\ \mathrm{Sa} & =\text { Sonneratia alba } \\ \mathrm{Rm} & =\text { Rhizophora mucronata } \\ \mathrm{Sc} & =\text { Sonneratia caseolaris } \\ \mathrm{Cd} & =\text { Ceriops decandra } \\ \mathrm{Ct} & =\text { Ceriops tagal } \\ \mathrm{Bg} & =\text { Bruguiera gymnorrhiza } \\ \mathrm{Aa} & =\text { Avicennia alba }\end{array}$

Analisis vegetasi kategori anakan pohon disajikan pada Tabel 5.

Tabel 5. Indeks Nilai Penting Kategori Anakan Pohon

\begin{tabular}{cccccc}
\hline No & S & KR(\%) & FR(\%) & DR(\%) & INP \\
\hline 1 & Sa & 23,81 & 14,29 & 19,46 & 57,55 \\
2 & Rm & 4,76 & 7,14 & 5,55 & 17,46 \\
3 & Sc & 14,29 & 14,29 & 11,42 & 39,99 \\
4 & Cd & 13,10 & 14,29 & 5,99 & 33,38 \\
5 & Ct & 7,14 & 7,14 & 8,25 & 22,53 \\
6 & Bg & 10,71 & 14,29 & 8,97 & 33,97 \\
7 & Aa & 15,48 & 14,29 & 22,59 & 52,35 \\
8 & Xg & 8,33 & 7,14 & 13,93 & 29,41 \\
9 & Ra & 2,38 & 7,14 & 3,83 & 13,35 \\
\hline
\end{tabular}

Keterangan:

$\begin{array}{ll}\mathrm{S} & =\text { Spesies } \\ \mathrm{KR} & =\text { Kerapatan Relatif } \\ \mathrm{FR} & =\text { Frekuensi Relatif } \\ \mathrm{DR} & =\text { Dominansi Relatif }\end{array}$

$$
\begin{array}{ll}
\mathrm{INP} & =\text { Indeks Nilai Penting } \\
\mathrm{Sa} & =\text { Sonneratia alba } \\
\mathrm{Rm} & =\text { Rhizophora mucronata } \\
\mathrm{Sc} & =\text { Sonneratia caseolaris } \\
\mathrm{Cd} & =\text { Ceriops decndra } \\
\mathrm{Ct} & =\text { Ceriops tagal } \\
\mathrm{Bg} & =\text { Bruguiera gymnorrhiza } \\
\mathrm{Aa} & =\text { Avicennia alba } \\
\mathrm{Xg} & =\text { Xylocarpus granatum } \\
\mathrm{Ra} & =\text { Rhizophora apiculata }
\end{array}
$$

Spesies Sonneratia alba mendominasi zonasi B pada kategori pohon dan anakan pohon, hal tersebut dikarenakan posisi pada zonasi B lebih mendekati sungai jika dibandingkan dengan zonasi A dan C. Noor et al. (2012) menyatakan bahwa Avicennia alba sangat sesuai tumbuh di sepanjang pinggiran sungai yang dipengaruhi oleh pasang surut (Noor et al., 2012). Sonneratia alba pada zonasi B jarang dimanfaatkan oleh masyarakat sekitar disebabkan posisi zonasi yang ada di tengah antara zonasi $\mathrm{A}$ dan zonasi $\mathrm{B}$, sehingga sulit untuk dijangkau. Berbeda dengan Rhizophora mucronata dan Rhiophora apiculata pada kategori pohon dan anakan pohon, memiliki jumlah sangat rendah disebabkan oleh kepiting mangrove yang bersimbiosis pada batang Rhizophora untuk memakan kulit batang, sehingga menghambat proses pertumbuhannya (Noor et al., 2012; Huge et al., 2016).

Tabel 6. Indeks Nilai Penting Kategori Semai

\begin{tabular}{ccccc}
\hline No & S & KR(\%) & FR(\%) & INP \\
\hline 1 & Rm & 15,15 & 14,29 & 29,44 \\
2 & Sa & 18,18 & 14,29 & 32,47 \\
3 & Aa & 9,09 & 14,29 & 23,38 \\
4 & $\mathrm{Bg}$ & 9,09 & 14,29 & 23,38 \\
5 & $\mathrm{Ct}$ & 18,18 & 14,9 & 32,47 \\
6 & $\mathrm{Ra}$ & 18,18 & 14,29 & 32.47 \\
7 & $\mathrm{Xg}$ & 12,12 & 14,29 & 26,41 \\
\hline
\end{tabular}

Keterangan:

$S=$ Spesies

$\mathrm{KR}=$ Kerapatan Relatif

$\mathrm{FR} \quad=$ Frekuensi Relatif

DR = Dominansi Relatif

INP = Indeks Nilai Penting 


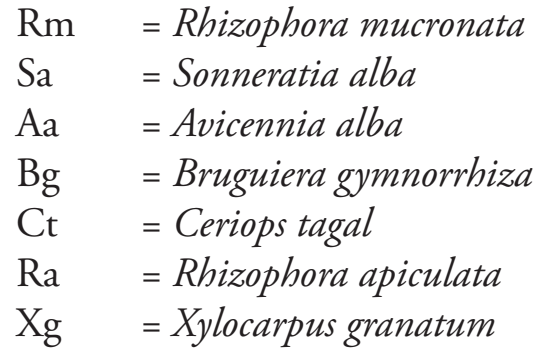

Spesies Sonneratia alba, Ceriops tagal, Rhizophora apiculata mendominasi pada zonasi B kategori semai, disebabkan karena tekstur tanah liat pada zonasi B sesuai untuk tempat tumbuh dari ketiga spesies tersebut. Noor et al. (2012) menyatakan bahwa substrat tanah liat sangat sesuai untuk media pertumbuhan spesies Sonneratia alba, Ceriops tagal, Rhizophora apiculata. Berbeda dengan Avicennia alba dan Bruguiera gymnorrhiza yang memiliki jumlah terendah, dikarenakan kondisi perairan di zonasi B terolong payau dengan tekstur tanah liat. Noor et al. (2012) menyatakan bahwa Avicennia alba dan Bruguiera gymnorrhiza bisa tumbuh secara optimal dengan kondisi perairan asin dan tekstur tanah liat berpasir.

Analisis vegetasi zonasi C Kategori pohon yang berada di lokasi $50 \mathrm{~m}$ dari darat disajikan pada Tabel 7.

Tabel 7. Indeks Nilai Penting Kategori Pohon

\begin{tabular}{cccccc}
\hline No & S & KR(\%) & FR(\%) & DR(\%) & INP \\
\hline 1 & Xg & 26,09 & 28,57 & 28,43 & 83,09 \\
2 & Lr & 43,48 & 42,86 & 46,07 & 132,40 \\
3 & Aa & 13,04 & 14,29 & 8,40 & 35,72 \\
4 & Bp & 17,39 & 14,29 & 17,10 & 48,78 \\
\hline
\end{tabular}

Keterangan:

$\begin{array}{ll}\mathrm{S} & =\text { Spesies } \\ \mathrm{KR} & =\text { Kerapatan Relatif } \\ \mathrm{FR} & =\text { Frekuensi Relatif } \\ \mathrm{DR} & =\text { Dominansi Relatif } \\ \mathrm{INP} & =\text { Indeks Nilai Penting } \\ \mathrm{Xg} & =\text { Xylocarpus granatum } \\ \mathrm{Lr} & =\text { Lumnitzera racemosa } \\ \mathrm{Aa} & =\text { Avicennia alba } \\ \mathrm{Bp} & =\text { Bruguiera parfiflora }\end{array}$

Spesies Lumnitzera racemosa mendominasi di zonasi C pada kategori pohon, disebabkan tekstur tanah liat pada zonasi $\mathrm{C}$ sesuai dengan tempat tumbuhnya. Noor et al. (2012) menyatakan bahwa subsrat yang cocok untuk tempat tumbuh spesies Lumnitzera racemosa adalah berlumpur padat. Berbeda dengan Avicennia alba yang memiliki jumlah terendah, disebabkan kondisi perairan pada zonasi C sebesar 4 ppt. Noor et al. (2012) menyatakan bahwa Avicennia alba bisa tumbuh secara optimal dengan kondisi perairan lebih dari 7 ppt.

Tabel 8. Indeks Nilai Penting Kategori Anakan Pohon

\begin{tabular}{cccccc}
\hline No & S & KR(\%) & FR(\%) & & INP \\
\hline 1 & Xg & 41,67 & 28,57 & 42,79 & 113,03 \\
2 & $\mathrm{Lr}$ & 25 & 42,86 & 26,04 & 93,90 \\
3 & $\mathrm{Aa}$ & 25 & 14,29 & 20,95 & 60,24 \\
4 & $\mathrm{Bp}$ & 8,33 & 14,29 & 10,21 & 32,83 \\
\hline
\end{tabular}

Keterangan:

$$
\begin{array}{ll}
\mathrm{S} & =\text { Spesies } \\
\mathrm{KR} & =\text { Kerapatan Relatif } \\
\mathrm{FR} & =\text { Frekuensi Relatif } \\
\mathrm{DR} & =\text { Dominansi Relatif } \\
\mathrm{INP} & =\text { Indeks Nilai Penting } \\
\mathrm{Xg} & =\text { Xylocarpus granatum } \\
\mathrm{Lr} & =\text { Lumnitzera racemosa } \\
\mathrm{Aa} & =\text { Avicennia alba } \\
\mathrm{Bp} & =\text { Bruguiera parfiflora }
\end{array}
$$

Spesies Xylocarpus granatum mendominasi pada zonasi C kategori anakan pohon, disebabkan karena zonasi $\mathrm{C}$ salinitasnya sebesar 4 ppt dan kondisi lokasi jarang tergenang air payau. Noor et al. (2012) menyatakan bahwa Xylocarpus granatum tumbuh optimal pada dua jenis lokasi, yaitu perairan payau dan lokasi yang berada di pinggir daratan dari mangrove serta jarang mengalami genangan air. Berbeda dengan Bruguiera parffflora memiliki jumlah terendah, disebabkan salinitas 4 ppt dan substrat liat yang tidak sesuai dengan tempat tumbuhnya. Noor et al. (2012) menyatakan bahwa substrat yang 
sesuai untuk tempat tumbuh Bruguiera parfiflora adalah lumpur berpasir dengan salinitas perairan lebih dari 7 ppt.

Tabel 9. Indeks Nilai Penting Kategori Semai

\begin{tabular}{ccccc}
\hline No & S & KR(\%) & FR(\%) & INP \\
\hline 1 & Xg & 29,27 & 28,57 & 57,84 \\
2 & Lr & 31,71 & 28,57 & 60,28 \\
3 & Aa & 17,07 & 14,29 & 31,36 \\
4 & Bp & 14,63 & 14,29 & 28,92 \\
5 & Nf & 7,32 & 14,29 & 21,60 \\
\hline
\end{tabular}

Keterangan:

$\mathrm{S} \quad=$ Spesies

$\mathrm{KR} \quad=$ Kerapatan Relatif

FR = Frekuensi Relatif

$\mathrm{DR}=$ Dominansi Relatif

INP = Indeks Nilai Penting

$\mathrm{Xg} \quad=$ Xylocarpus granatum

$\mathrm{Lr} \quad=$ Lumnitzera racemosa

Aa $\quad=$ Avicennia alba

$\mathrm{Bp} \quad=$ Bruguiera parfiflora

$\mathrm{Nf} \quad=$ Nypa fruticans

Spesies Lumnitzera racemosa mendominasi di zonasi $\mathrm{C}$ pada kategori semai dan pohon, disebabkan tekstur tanah liat pada zonasi C sesuai dengan tempat tumbuhnya. Noor et al. (2012) menyatakan bahwa subsrat yang cocok untuk tempat tumbuh spesies Lumnitzera racemosa adalah berlumpur padat. Berbeda dengan Nypa fruticans yang memiliki jumlah terendah, disebabkan sistem penyerbukan yang tergantung oleh lalat Drosophila, jika populasi lalat di lokasi mangrove mengalami penurunan, otomatis akan mengganggu penyerbukan dan pembentukan buah Nypa fruticans (Noor et al., 2012).

Konservasi merupakan upaya untuk menjaga kondisi lingkungan dari kegiatan masyarakat setempat yang bersifat mengurangi (Daryono et al., 2016). Konservasi yang dilakukan pada kawasan mangrove Cengkrong harus mengetahui dan memahami tentang spesies tanaman mangrove yang sesuai dengan kondisi lingkungan dan mampu tumbuh di daerah tersebut. Hasil analisis vegetasi diperoleh berbagai macam spesies mangrove yang dapat dijadikan sebagai bahan rekomendasi kepada pemerintah dalam penanaman mangrove dan sebagai edukasi masyarakat setempat dalam pemilihan spesies mangrove untuk ditanam. Spesies yang mendominasi pada 3 zonasi yang ditentukan sebagai titik pengambilan sampel diantaranya adalah, zonasi A terdiri dari Sonneratia alba kategori pohon dan anakan pohon, Rhizophora mucronata kategori semai, zonasi B terdiri dari Sonneratia alba kategori pohon, anakan pohon, dan semai. Kategori semai terdiri Ceriops tagal, Rhizophora apiculata, zonasi C terdiri dari spesies Lumnitzera racemosa kategori pohon dan semai, Xylocarpus granatum kategori anakan pohon. Grafik tingkat spesies yang mendominasi pada kawasan mangrove Cengkrong disajikan pada Gambar 3.

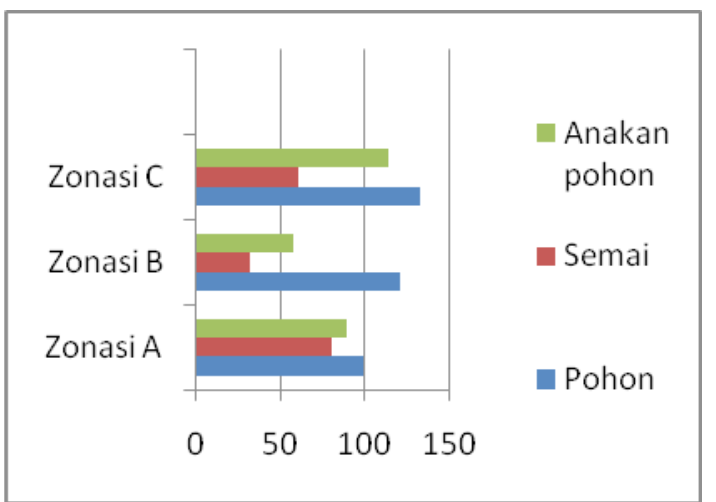

Gambar 3. Tingkat Spesies yang Mendominasi

Tabel 10. Spesies Mangrove untuk Rekomendasi

Konservasi Berdasarkan Faktor Lingkungan yang Mempengaruhinya.

\begin{tabular}{|c|c|c|c|c|c|c|c|}
\hline Zonasi & $S$ & \multicolumn{6}{|c|}{ Faktor Lingkungan } \\
\hline & & $\mathbf{a}$ & b & C & d & e & $\mathrm{f}$ \\
\hline A & $\begin{array}{c}\mathrm{Sa} \\
\mathrm{Rm}\end{array}$ & 31 & 32 & 6 & 6,4 & Liat & 57,37 \\
\hline B & $\begin{array}{l}\mathrm{Sa} \\
\mathrm{Ct} \\
\mathrm{Ra}\end{array}$ & 30 & 31 & 6 & 6,7 & Liat & 50,26 \\
\hline C & $\begin{array}{l}\mathrm{Xg} \\
\mathrm{Lr}\end{array}$ & 29 & 30 & 4 & 6,9 & Liat & 43,7 \\
\hline
\end{tabular}

Keterangan:

$\mathrm{S} \quad=$ Stasiun

$\mathrm{a} \quad=$ Suhu air $\left({ }^{\circ} \mathrm{C}\right)$

$\mathrm{b} \quad=$ Suhu udara $\left({ }^{\circ} \mathrm{C}\right)$

c $\quad=$ Salinitas (ppt) 
$\mathrm{d} \quad=\mathrm{pH}$ substrat

$\mathrm{e} \quad=$ Tekstur tanah

$\mathrm{f}=$ Kandungan air pada tanah

$\mathrm{Sa} \quad=$ Sonneratia alba

$\mathrm{Rm}=$ Rhizophora mucronata

$\mathrm{Ct} \quad=$ Ceriops tagal

$\mathrm{Ra}=$ Rhizophora apiculata

$\mathrm{Xg} \quad=$ Xylocarpus granatum

$\mathrm{Lr} \quad=$ Lumnitzera racemosa

3. Pendekatan Kepada Masyarakat untuk Berpartisipasi dalam Konservasi Mangrove Berbasis TRM

Pendekatan awal yang dilakukan oleh DKP (Dinas Kelautan Perikanan) kepada masyarakat bertujuan untuk memulai konservasi melalui Pokmaswas (Kelompok Pengawas Masyarakat) dibentuk oleh DKP pada tahun 2008 dan disahkan dalam Surat Keputusan Kepala DKP Kabupaten Trenggalek Nomor 188.45/842/406.060/2008. Pokmaswas bertugas untuk melaporkan terjadinya kasuskasus dalam lingkup kelautan perikanan dan menjalankan fungsi sebagai pelaksana, pengawas, dan pengendalian dalam pengelolaan serta pemanfaatan sumberdaya perikanan kelautan di tingkat lapangan (Purwanti et al., 2015). Hutan mangrove sangat rentan dengan kerusakan apabila kurang bijaksana dalam mempertahankan, mengelola, dan melestarikan (Hinricks et al., 2008; Novianty et al., 2012). Pelestarian tumbuhan mangrove sangat membutuhkan peran dari masyarakat setempat (Ritohardoyo, 2009; Abdullah, 2014). Keraf (2002) menyatakan bahwa manusia mempunyai kepentingan untuk melestarikan lingkungan, karena dengan melestarikan lingkungan, manusia sudah berusaha untuk mempertahakan hiupnya. Hasil wawancara kepada Pokmaswas Kejung Samudera berdasarkan tingkat partisipasinya dalam pengelolaan kawasan mangrove Cengkrong disajikan pada Tabel 11.
Tabel 11. Pendapat Pokmaswas Kejung Samudera Berdasarkan Tingkat Partisipasi N=33.

\begin{tabular}{llll}
\hline \multicolumn{1}{c}{ Deskripsi } & Min & Maks & \multicolumn{1}{c}{ R } \\
\hline 1. PL & & & \\
\hline A1 & 6 & 7 & 6,5 \\
A2 & 5 & 7 & 6,0 \\
Total & & & 6,25 \\
B1 & 4 & 8 & 6,0 \\
B2 & 3 & 8 & 5,5 \\
Total & & & 5,75 \\
C1 & 2 & 8 & 5,0 \\
C2 & 2 & 7 & 4,5 \\
Total & & & 4,75 \\
\hline 2. PTL & & & \\
\hline D1 & 5 & 7 & 6,0 \\
D2 & 5 & 7 & 6,0 \\
Total & & & 6,0 \\
\hline
\end{tabular}

Keterangan:

$\mathrm{R}=$ Rata-rata

PL = Patisipasi Langsung

A1 = Kehadiran dalam rapat (perencanaan)

A2 = Keaktifan menyampaikan usulan (perencanaan).

B1 = Keikutsertaan dalam kegiatan penanaman pohon (pelaksanaan)

B2 = Keikusertaan dalam perawatan dan pengamanan hutan (pelaksanaan)

$\mathrm{C} 1$ = Aktif dalam monitoring hutan (pengawasan)

C2 = Aktif melapokan tindakan pelanggaran oleh masyarakat dan petugas (pengawasan)

PTL = Partisipasi Tidak Langsung

D1 = Ketaatan terhadap aturan perundangundangan

D2 = Ketaatan terhadap peraturan daerah

Tingkat partisipasi masyarakat sekitar melalui Pokmaswas dalam kegiatan Tanam, Rawat, Monitoring, dan aktif dalam melaporkan tindakan pelanggaran oleh masyarakat serta petugas, menduduki kategori rendah, dengan 
nilai $(5,75$ dan 4,75). Oleh karena itu, kawasan mangrove Cengkrong harus diterapkan srategi konservasi berbasis TRM (Tanam Rawat Monitoring).

\section{Strategi Konservasi Mangrove Berbasis TRM}

Model konservasi secara lama, hanya memakai sistem tanam mangrove, sehingga dalam pembagian tugas untuk rawat dan monitoring mangrove belum ada hasil yang signifikan. Kerja nyata Pokmaswas Kejung Samudera sampai saat ini masih dalam tahap penanaman, sehinga perlu adanya pembaharuan model kebijakan dari pemerintah daerah khususnya Dinas Kelautan Perikanan tentang perawatan dan monitoring mangrove di Cengkrong. Menelaah kejadian yang demikian, maka strategi konservasi berbis TRM harus diterapkan pada kawasan mangrove Cengkrong. Strategi TRM memberikan porsi yang lebih kepada masyarakat setempat, melalui Pokmaswas untuk menjaga keberadaan mangrove supaya tetap terjaga keseimbangan ekosistemnya. Tinggi atau rendahnya apresiasi masyarakat sekitar berpengaruh terhdap keberhasilan suatu program (Moriizumi et al., 2010; Christiansen et al., 2016; Yuniarti et al., 2016)

Strategi konservasi mangrove berbasis TRM sebagai solusi untuk role model dalam menjaga keberadaan mangrove dari kerusakan dan bisa digunakan sebagai pembaharuan kebijakan di Kabupaten Trenggalek. Konservasi yang seharunya diterapkan di kawasan mangrove Cengkrong tersaji pada Gambar 4.

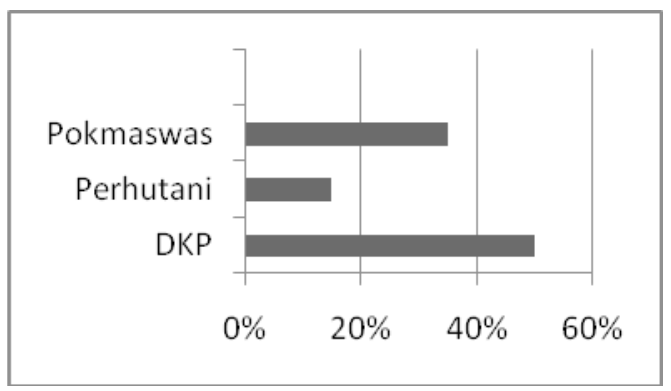

(a)

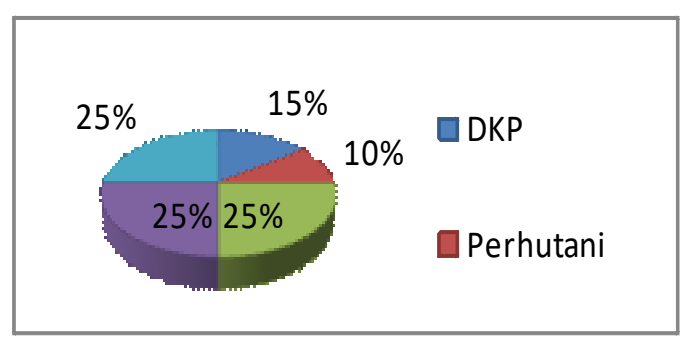

(b)

Gambar 4. Pembaharuan Model Kebijakan (a) Model lama hanya memakai konsep tanam, (b) Model baru memakai konsep TRM.

Strategi TRM difokuskan untuk melakukan pendekatan kepada masyarakat dengan memberdayakan Kelompok Pengawas Masyarakat yang berjulah 33 orang. Amrial et al. (2015) menyatakan bahwa pendekatan partisipatif dan kemitraan oleh Dinas Kelautan Perikanan dan Perhutani kepada masyarakat sekitar perlu dilakukan, karena mangrove merupakan salah satu penopang sumber daya laut. Jumlah 33 orang yang masuk dalam Pokmaswas tersebut dibagi menjadi tiga kelompok yang ditugaskan untuk menangani Tanam mangrove 11 orang, Rawat mangrove 11 orang, dan Monitoring mangrove 11 orang. Harapannya semakin jelas pembagian tugas, maka semakin nampak perubahan yang lebih baik bagi kawasan mangrove Cengkong. Peran DKP (Dinas Kelautan Perikanan) dan Perhutani dalam hal ini adalah sebagai fasilitator dan pengarah. Kunci keberhasilan suatu program terletak pada dukungan penuh dari pemerintah (Qiu et al., 2013; Bidayani et al., 2016).

\section{Simpulan}

INP mangrove (1) zonasi A didominasi Sonneratia alba $(99,84)$ kategori pohon, Sonneratia alba $(89,03)$ kategori anakan pohon, Rhizophora mucronata $(80,74)$ kategori semai, zonasi B didominasi Sonneratia alba $(120,57)$ kategori pohon, Sonneratia alba $(57,55)$ kategori anakan pohon, Sonneratia alba, Ceriops tagal, Rhizophora apiculata $(32,47)$ kategori semai, zonasi C didominasi Lumnitzerra racemosa $(132,40)$ kategori pohon, Xylocarpus granatum 
$(113,03)$ kategori anakan pohon, Lumnitzerra racemosa $(60,28)$ kategori semai. (2) Pendekatan yang diterapkan kepada masyarakat sekitar oleh Dinas Kelautan Perikanan dan Perhutani dengan membentuk Kelompok Pengawas Masyarakat bernama Kejung samudera secara partisipatif dan kemitraan. (3) Penerapan strategi konservasi berbasis TRM di hutan mangrove Cengkrong lebih efektif untuk diterapkan, dibanding dengan strategi berbais sosialisasi yang bersifat teori, sehingga harapannya model konservasi ini bisa dibuat sebagai tambahan dalam membuat kebijakan sosial terkait dengan model konservasi mangrove untuk menjaga keberadaan hutan mangrove tetap lestari dan menjaga sumberdaya laut tetap seimbang keberadaannya.

\section{Daftar Pustaka}

Abdullah, K., Said, A.M., \& Omar, D. (2014). Community Based Conservation in Managing Mangrove Rehabilitation in Perak and Selangor. Journal Social and Behavioral Sciences. 153, 121-131.

Amrial, Y., Effendi, H., \& Damar, A. (2015). Pengelolaan Ekosistem Mangrove Berbasis Silvofishery di Kecamatan Cibuaya, Kabupaten Karawang. Jurnal Kebijkan Sosial Ekonomi Kelautan dan Perikanan. 5, 59-70.

Badan Pusat Statistik. (2016). Kecamatan Watulimo dalam Angka 2016. BPS Trenggalek: Trenggalek.

Bidayani, E., Soemarno., Harahap, N., \& Rudianto. (2016). Blue Economy Approach Based Mangrove Resources Conservation for Coastal Community's Prosperity in Sidoarjo Regency, East Java, Indonesia. International Journal of Ecosystem. 6, 1-9.

Bengen, D.G. (2000). Pedoman Teknis Pengenalan dan Pengelolaan Ekosistem Mangrove. Pusat Kajian Sumberdaya Pesisir dan Laut: Bogor.

Chandra, I. A., Seca, G., \& Hena, A.M.K. (2011). Aboveground Biomass Production of Rhizophora apiculata Blume in Sarawak Mangrove Forest. Journal Agricultural and Biological Sciences. 6, 469-474.

Christiansen, S.D., Guzman, T.L., \& Galves, J.C.P. (2016). Motivations and Valued Attributes of Ecotourism in a Natural Protected Area: Santay Island (Ecuador). Journal Mediteran of Social Sciences. 7, 240-249.

Dahdouh-Guebas, F., C Mathenge, J.G., Kairo., N Koedam. (2000). Utilization Mangrove Wood Products Around Mida Creek (Kenya) Among Subsistence and Comercial Users. Journal Economic Botany. 54, 513-527.

Dahuri, Rochmin., Jacob Rais., Sapta Putra Ginting., \& M.J Sitepu. (2001). Pengelolaan Sumberdaya Wilayah Pesisir dan Lautan Secara Terpadu. Pradnya Paramita: Jakarta.

Daryon, B.S., Sidiq, Y., \& Maryanto, S.D. (2016). Pengembangan Serta Budidaya Melon di Pantai Bocor Kabupaten Kebumen Melalui Implementasi Education for Sustainable Development. Jurnal Bioeksperimen. 2, 44-53.

De Silva, K.H.W.L., \& Amarasinghe, M.D. (2010). Vegetative Propagation of Some Selected Mangrove Species from Negombo Estuary, Sri Lanka. Journal Aquast Sci. 15, 25-38.

Dinas Kelautan Perikanan. (2016). Rehabilitasi Hutan Mangrove. Berita Acara Rehabilitasi Hutan Mangrove di Kabupaten Trenggalek: Trenggalek.

Elhaq, I.H., \& Satria, A. (2011). Persepsi Pesanggem Mengenai Hutan Mangrove dan Partisipasi Pesanggem dalam Pengelolaan Tambak Mangrove Ramah Lingkungan Model Empang Parit. 
Jurnal Transdisiplin Sosiologi, Komunikasi, dan Ekologi Manusia. 5, 97-103.

Hinricks, S., Nordhaus, I., \& Geist, S.J. (2008). Status Diversity and Distribution Patterns of Mangrove Vegetation in the Segara Anakan Lagon Java Indonesia. Journal Environ Change. 9, 275-289.

Huge, J., Velde, K.V., Capistros, F.B., Japay, J.H., Satyanarayana, B., Ishak, M.N., Zuniga, M.Q., Lokman, Bin H.M., Sulong, I., Koedam, N., \& Guebas, F.D. (2016). Mapping Discourses Using Q Methodology in Matag Mangrove Forest. Journal Environmental Management. 183, 988-997.

Kartijono, N.E., Rahayuningsih, M., \& Abdullah, M. (2010). Keanekaragaman Jenis Vegetasi dan Profil Habitat Burung di Hutan Mangrove Pulau Nyamuk Taman Nasional Karimunjawa. Jurnal Biosaintifika. 2, 27-39.

Kaunang, T.D., Kimbal, J.D. (2009). Komposisi Struktur Vegetasi Hutan Mangrove di Taman Nasional Bunaken Sulawesi Utara. Jurnal Agritek. 17, 1163-1171.

Keraf, A.S. (2002). Etika Lingkungan. Kompas Media Nusantara: Jakarta.

Krebs, C.J. (1972). The Experimental Analysisof Distribution and Abundance. Harper International: New York.

Kustanti, A. (2011). Manajemen Hutan Mangrove. Institu Pertanian Bogor Press: Bogor.

Mahmudi, M., Nuddin H., \& Diana, A. (2007). Daya Dukung Ekologi dan Ekonomi Ekosistem Mangrove Terhadap Produksi Perikanan sebagai Dasar Pengelolaanm Sumberdaya Mangrove di Wilayah Pesisir. Kementerian Negara Riset dan Teknologi Republik Indonesia: Jakarta.

Moriizumi, Y., Matsui, N., \& Handono, H. (2010). Simplified Life Cycle Sustainability Assessment of Mangrove Management: A Case of Plantation on Westelands in Thailand. Journal Cleaner Production. 18, 1629-1638.

Noor, J. (2011). Metodologi Penelitian. Prenadarmedia Group: Jakarta.

Noor, Y.R., Khazali, M., \& Suryadiputra, I.N.N. (2012). Panduan Pengenalan Mangrove Indonesia. Perlindungan hutan konservasi alam WI-IP: Bogor.

Novianty, R., Sastrawibawa, S., \& Juliandri, D. (2012). Identifikasi Kerusakan dan Upaya Rehabilitasi Ekosistem Mangrove di Pantai Utara Kabupaten Subang. Jurnal Perikanan dan Kelautan. 3, 41-47.

Orizal., Kusmana, C. (2008). Studi Ekologi Hutan Mangrove di Pantai Timur Sumatera Utara. Jurnal Biodiversitas. 9, 25-29.

Pranata, R.T.H., \& Satria, A. (2015). Strategi Adaptasi Nelayan Terhadap Penetapan Kawaan Konservasi Perairan Daerah di Misool Selatan, KKPD Raja Ampat. Jurnal Kebijakan Sosial Ekonomi Kelautan dan Perikanan. 5, 113-128.

Qiu, W., \& Jones, P.J.S. (2013). The Emerging Policy Landscape For Marine Spatial Planing in Europe. Journal Marine Policy. 39, 182-190.

Ritohardoyo, S. (2009). Ekologi Manusia. Program Studi Ilmu Lingkungan. Sekolah Pasca Sarjana UGM: Yogyakarta.

Saputra, S.W. (2003). Kondisi Perairan Segara Anakan Ditinjau dari Indikator Biotik. Pascasarjana Institut Pertanian Bogor: Bogor.

Sarno. (2016). Penanaman Mangrove di Dalam Pot. Jurnal Bioeksperimen. 2, 17-24. 
Sulastini, D. (2011). Mangrove Taman Nasional Alas Purwo. Balai Taman Nasional: Banyuwangi.

Susanto, A.H., Soedarti, T., \& Purnobasuki, H. (2013). Struktur Komunitas Mangrove di Sekitar Jembatan Suramadu Sisi Surabaya. Jurnal Bioscientiae. 10, 1-10.

Susilo, E., Purwanti, P., \& Lestariadi, R.A. (2015). Keberlanjutn "Kejung Samudera" dalam Pengelolaan dan Pemanfaatan Sumberdaya Mangrove di Pancer Cengkrong dan Damas, Pantai Prigi, Trenggalek. Jurnal Kebijakan Sosial Ekonomi Kelautan dan Periknan. 5, 19-25.

Susilowati, I., Muhajirin T., Waridin, Tri W., \& Agung S. (2005). Pengembangan Model Pemberdayaan Masyarakat Pesisir (Usaha Mikro, Kecil Menengah Dan Koperasi UMKMK) dalam Mendukung Ketahanan Pangan di Kabupaten/ Kota Pekalongan, Jawa Tengah. Riset Unggulan Kemasyarakatan dan Kemitraan: Jakarta.

Van, T.T., Wilson, N., Tung, H.T., Quisthoudt, K., Minh, V.Q., Tuan, L.X., Guebas, F.D., \& Koedam, N. (2015). Changes In Mangrove Vegetation Area And Character In A War And Land Use Change Affected Region Of Vietnam (Mui Ca Mau) Over Six Decades. Journal Oecologica. 63, 71-81.

Yanuartanti, I.W., Kusmana, C., \& Ismail, A. (2015). Kelayakan Rehabilitasi Mangrove Dengan Teknik Guludan Dalam Perspektif Perdagangan Karbon Di Kawasan Hijau Lindung Muara Angke, Provinsi Dki Jakarta. Jurnal Pengelolaan Sumberdaya Alam dan Lingkungan. 5, 180186.

Yuniartati, I., Triyanto., Wijaya, N.I., Lestari, F.S., Setiawan, F., \& Sutrisno. (2016). Mangrove of Berau: Ecological Conditions, Fisheries, and Management Options. Journal Indonesian Fisheries Research. 22, 37-42.

Zamroni, Y., \& Rohyani, I.S. (2008). Produksi Serasah Hutan Mangrove di Perairan Pantai Teluk Sepi, Lombok Barat. Jurnal Biodiversitas. 9, 284-287. 